\title{
股関節に発生した滑膜骨軟骨腫症の治療経験
}

$$
\text { 茶川一樹*田中浩* 礒 部 淳 - * 田口敏 彦* }
$$

\section{Treatment of Synovial Osteochondromatosis of the Hip Joint}

\author{
Kazuki Chagawa*, Hiroshi Tanaka*, Jyunichi Isobe*,
} and Toshihiko Taguchi*

【はじめに】滑膜骨軟骨腫症は滑膜内に骨軟骨組織が形成され遊離体の生じる疾患であり，膝・肘関節 に多く, 股関節に発生するのは比較的まれである. 病期分類として Milgram 分類が有名である. 【症例】 股関節に滑膜骨軟骨腫症の発生した $24 \sim 44$ 歳の男性 2 名，女性 1 名. いずれも遊離体摘出十滑膜切除施 行し, Milgram 分類 2 期の診断であった. 24 歳の男性に残存病変からの再発を認めた. 【考察】画像診 断が有用であり，特に CT, MRI，関節造影がより有用である。保存的療法は効果に乏しく，一般には手 術療法が選択される。遊離体の完全摘出と十分な滑膜切除が望ましいと考えられ，このためには脱臼操作 が必要と思われるが, 骨頭壊死の危険性があり, 可能であれば避けるべきである.【結語】股関節に生じ た滑膜骨軟骨腫症の 3 例を経験した。若年発生例において残存・再発症例を認めた。脱臼操作を行わない 手術法が好ましいと思われる。

Synovial Osteochondromatosis is a disease which forms osteochondroma in the synovial membrane, and free bodies. The disease breaks out in the knee and elbow joint mainly but rarely in the hip joint. The classification of Milgram is famous. We experienced two men and one woman which had the disease and their age range was 24 to 44 years old. All patients were treated by removal of the free bodies and synovectomy and classified Stage 2 of Milgram. Only a 24-year-old patient felt pain again due to left free bodies. For diagnosis of the disease, CT, MRI, and arthrography are more useful. Conservative treatments are not effective, and operative treatments are selected in general. A treatment that removes free body completely and resects synovium adeduately is desirable. Dislocation of the femoral head is considered necessary for this treatment, but should be avoided because it may cause avascular necrosis of the femoral head. We experienced three cases of synovial osteochondromatosis and treated by operation without dislocation of the femoral head. This method can prevent complications of the avascular necrosis of the femoral head.

Key words : synovial osteochondromatosis (滑膜骨軟骨腫症), dislocation of the femoral head (大腿骨頭脱臼)， avascular necrosis of the femoral head（大腿骨頭壊死症）

$$
\text { は じめに }
$$

滑膜骨軟骨腫症は 1900 年に Rechel らが初めて報 告した良性の非腫瘍性疾患であり, 滑膜内に骨軟骨組 織が形成され遊離体を生じる疾患である，原因は不明 と言われているが，滑膜の未分化細胞が化生して多数 の硝子様軟骨を生じるという化生説が有力と考元られ ている. 30〜 40 歳の男性に好発し, 発生部位は膝関 節が $50 \%$ 以上，肘関節が $20 \%$ と多いが，股関節に発
生した例は約 $10 \%$ と比較的まれであり，股関節疾患

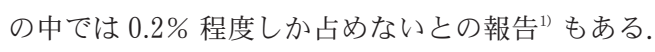
今回, 当院にて 3 例の股関節に発生した滑膜骨軟骨腫 症を経験したので報告する.

症例

症例 124 歳, 男性

主 訴 右股関節痛

現病歴 特に誘因無く上記主訴を自覚, 確定診断の

\footnotetext{
* 山口大学整形外科 Departmet of Orthopaedic Surgery, Yamaguchi University, Yamaguchi, Japan
} 

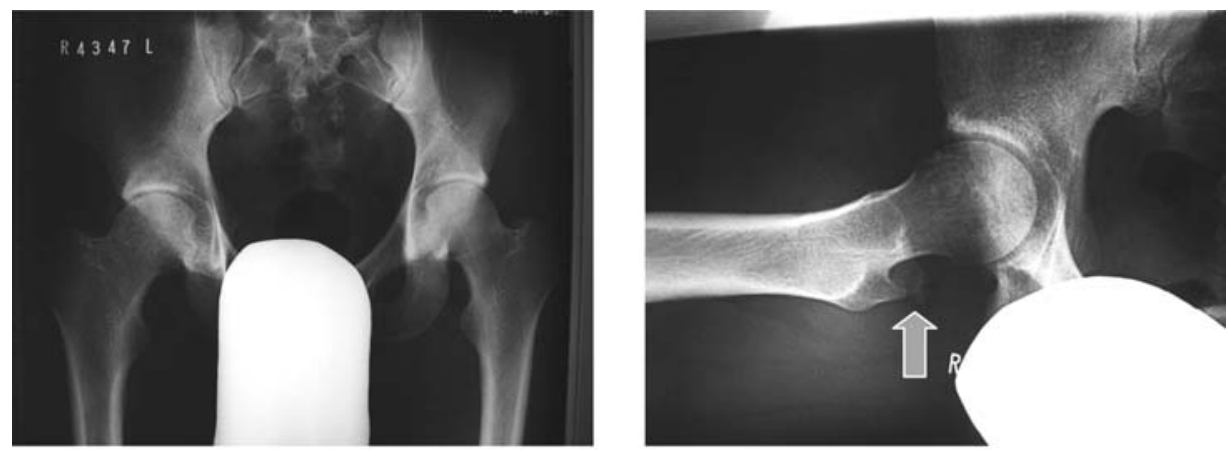

初診時 X-p：頝部にわずかに石灰化陰影が確認される.
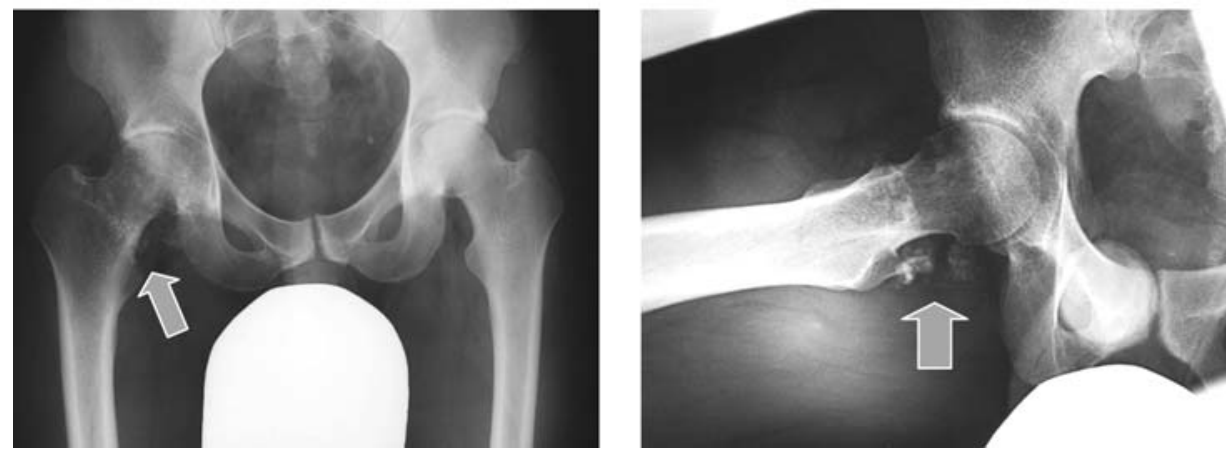

5 ケ月後 (入院時) X-p : 石灰化陰影の増大が認められる.

図 1

つかぬまま 4 ケ月経過観察された. その後 CT, MRI 精査施行され, 滑膜骨軟骨腫症と診断された.

既往歴 特記事項なし

入院時理学所見 歩行は limping を認め，右股関 節は外旋位をとつていた，骨頭部に圧痛を認め，明ら かな筋萎縮は認めなかつた。右股関節の可動域制限を 認め, 疼痛と crepitation 認めた. Patric sign 陽性 で，痛みのため Active SLR は不可であった。

画像所見 単純 $\mathrm{X}$ 線像にて初診時頚部にわずかに 石灰化陰影が確認され，5 ケ月後の入院時には石灰化 陰影の増大が認められる（図 1)。関節造影を施行す ると関節内に多発腫瘤の存在が疑われた（図 2). CT では頚部を中心に多数の骨化病変を認め（図 3), MRI では肥厚・増殖した滑膜と関節内水腫が認めら れ，T2 にて内部に多数の小結節の存在が疑われた (図 4).

手術所見 遊離体摘出十滑膜切除術を行つた. 前方 アプローチにて進入. 関節内に多数の遊離体, 滑膜増

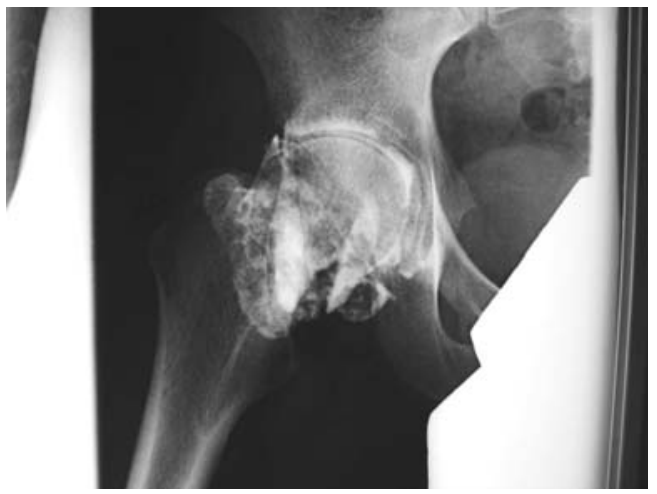

図 2 関節造影 : 関節内に多発腫瘤の存在が疑われる.

殖認め, Milgram phase II 期と診断. 脱臼操作行わ ず，大腿骨を可動させたり，水圧で押し出したりする ことによって可及的に遊離体の摘出と滑膜切除を行っ た. 遊離体の残存の無い事を透視下に確認して手術を 終了した（図 5). 

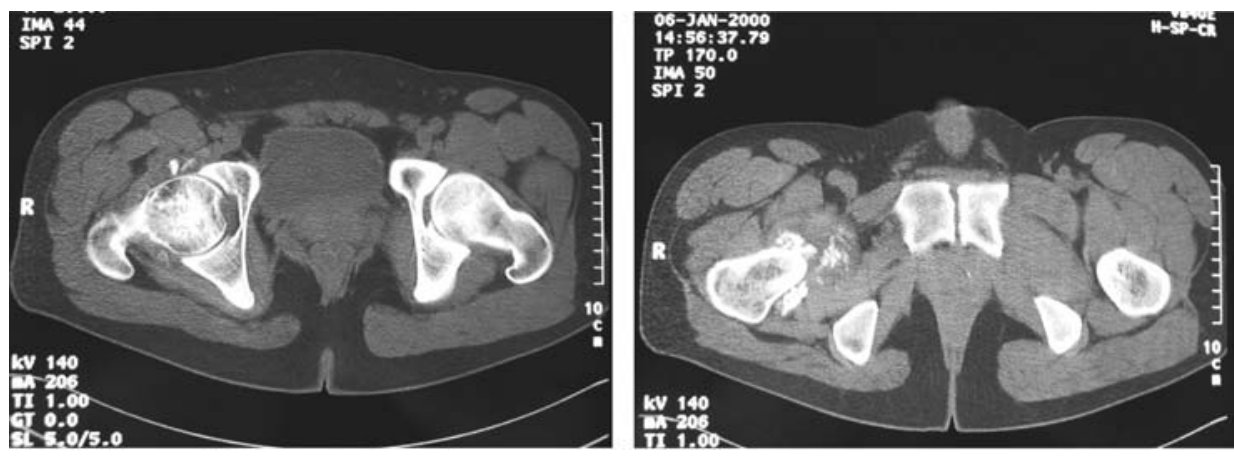

図 $3 \mathrm{CT}$ : 頚部を中心に多数の骨化病変が認められる.
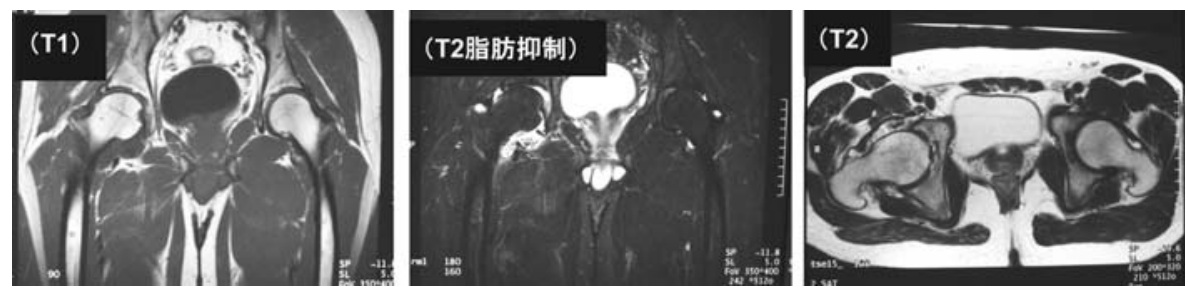

図 $4 \mathrm{MRI}$ : 肥厚・増殖した滑膜と関節内水腫が認められ，T2 にて内部に多数の小結節 の存在が疑われた。

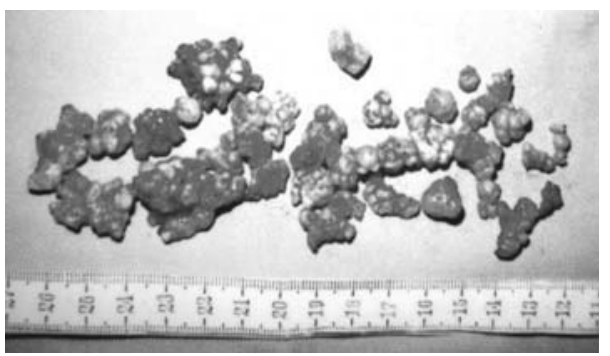

図 5 計 $21 \mathrm{~g}$ の遊離体摘出

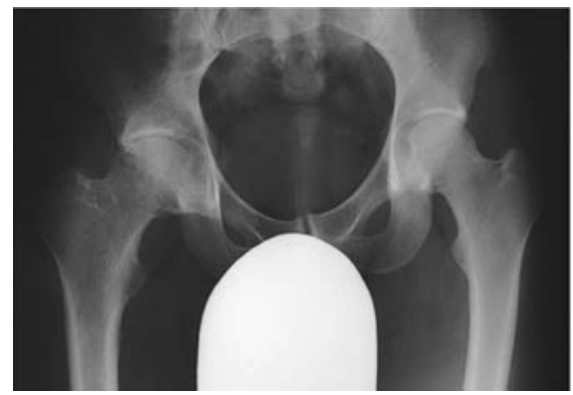

図 6 術後 X-p 術後経過＼cjkstart術後 3 日目に荷重開始．右股関節痛は軽 快し, 可動域も改善したが, 単純 X 線にて内側後方 に残存病変が認められた（図 6). 術後 1 年 10 ケ月で, 病変の拡大を認め, 3 年半経過時には, さらに増大し, 前方にも再発を認め, 症状の再燃も認めた. 8 年経過 した現在，右股関節痛は軽度持続しているが，骨化病 変の著明な増大は認めていない（図 7)。日常生活は 問題なく過ごし, 軽度であればスポーツ活動も可能で ある。また，明らかな関節症変化は現時点では認めな い.

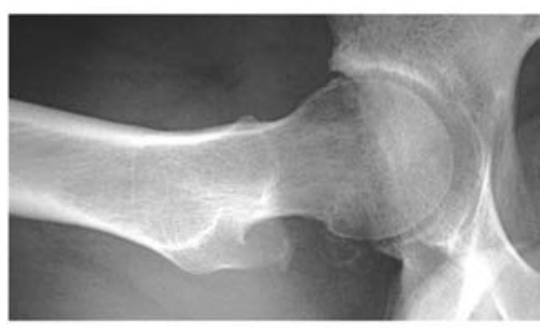


(術後 1 年 10 ケ月)
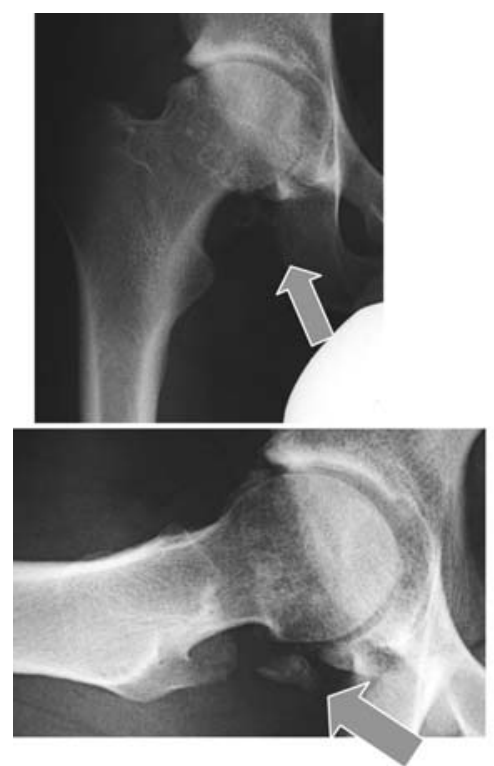

(術後 8 年)

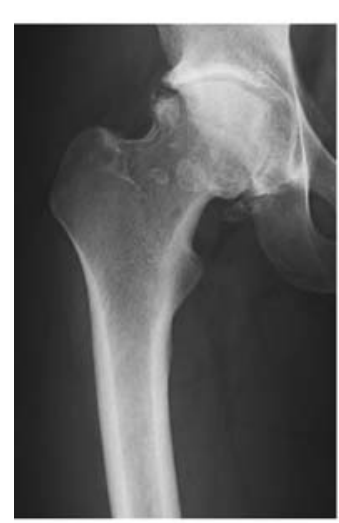

(術後 3 年半)
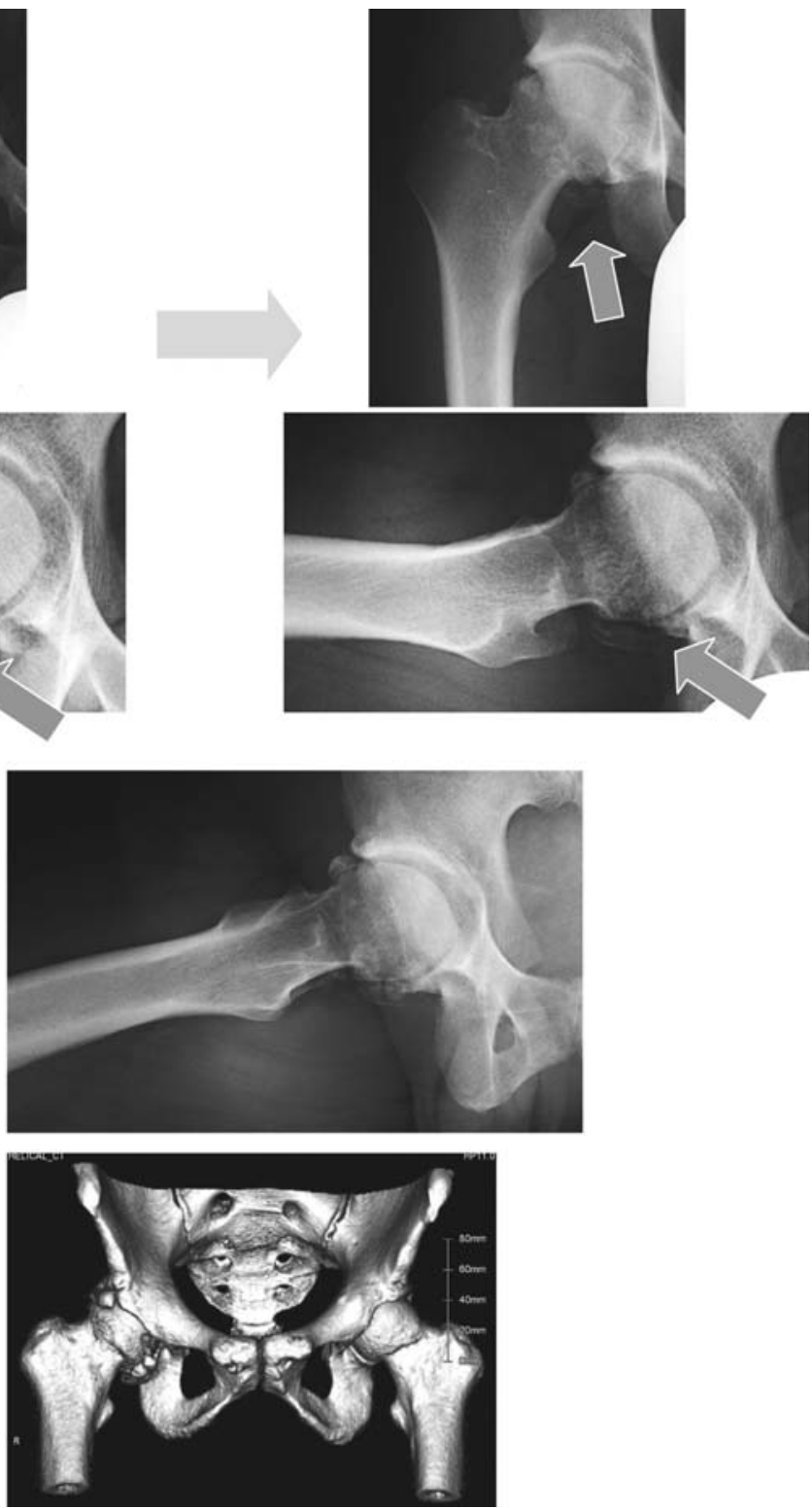

図 7 術後 1 年 10 ケ月で病変の拡大を認め, 3 年半経過時には, さらに増大, 前方にも 再発を認め, 症状の再燃も認めた. 8 年経過した現在, 右股関節痛は軽度持続して いるが, 骨化病変の著明な増大は認めていない.

症例 244 歳, 女性

主 訴 左股関節痛

現病歴 7 年前より上記主訴自覚. 近医にて保存的 加療を行うも軽快なく, 徐々に増悪を認めた. 歩行困
難を生じたため, CT・MRI にて精査を行い滑膜骨軟 骨腫症と診断された.

既往歴 糖尿病, 肝硬変

入院時理学所見 Trendenlenberg 歩行認め, 左股 

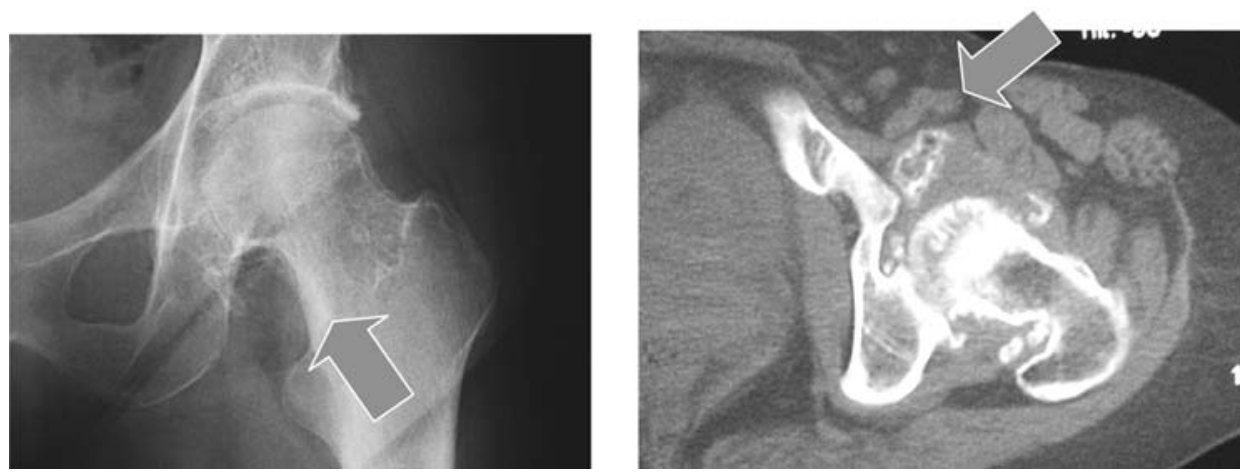

図 8 単純 X 線にて石灰化陰影, CT にて多発性の骨化腫瘤認めた.

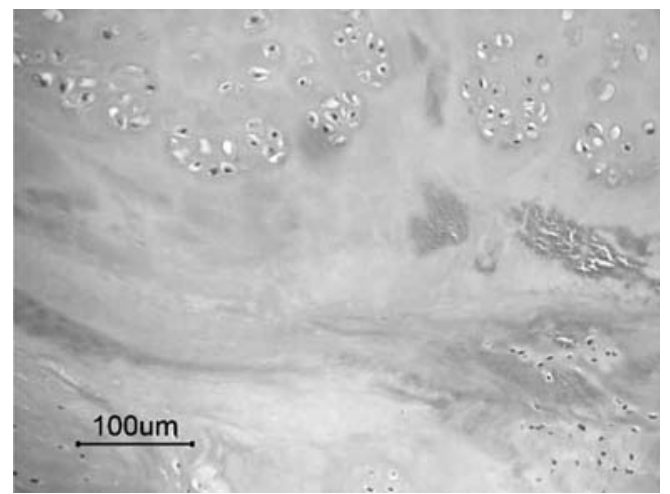

図 9 病理所見 骨化を伴う, 軟骨の分葉状の増生を 認めた.

関節周囲に著明な圧痛あり, 左下肢に筋萎縮を認めた. 可動域の低下と運動時痛認め, Patric sign 陽性だが, 片脚起立は可能であった.

画像所見 単純 X 線にて石灰化陰影, CT にて多発 性の骨化腫瘤認めた（図 8).

手術所見 前方アプローチにて進入, 増殖・肥厚し た滑膜を認め, Milgram phase II と診断. 脱臼操作 は行わず，触知できる範囲で全てを摘出した。計 $36 \mathrm{~g}$ の骨軟骨腫を摘出.

術後経過 症状は改善, 明らかな症状の再燃は認め ないが, CT にて少量の残存病変を認めた.

症例 333 歳, 女性

主 訴 左股関節痛

現病歴 約 8 年前より左股関節痛を自覚，以後症状 の寛解，増悪を繰り返すも，無治療であった。近医よ り当院紹介となつた.
既往歴 特記事項なし

身体所見 左股関節の疼痛と可動域障害を認めた. 画像所見 症例 1,2 と同様に骨化性病変を認めた. 手術所見 症例 1,2 と同様に脱臼操作は行わず前 方進入にて遊離体摘出 + 滑膜切除を行った.

病理所見 骨化を伴う, 軟骨の分葉状の増生を認め, 滑膜骨軟骨腫症と確定診断（図 9).

術後経過 明らかな残存病変は認めず，症状の再燃 も認めていない.

考察

滑膜骨軟骨腫症の診断では画像診断が有用であるが, 単純レントゲンでの石灰化は約 $30 \%$ に認める程度と の報告 ${ }^{2}$ がある， CT， MRI，関節造影がより有用で あると考えられる．確定診断には病理組織所見にて滑 膜内の軟骨化生の像を確認する必要があるとの報告も あるが, 臨床所見, 画像所見から診断は可能であると 考えられる.

治療法については，保存的療法は効果に乏しく遊離 体による関節軟骨の破壊から臨床症状の悪化, 変形性 関節症への進行の危険性あるため, 一般には手術療法 が選択される. Milgram は I , II 期には遊離体摘出 十滑膜切除を行い， III期には遊離体摘出のみでよいと 述べており， II 期では増殖・再発の可能性高く，成績 に差は生じないため, 広範囲の滑膜切除は不要で可及 的切除にとどめるべきとも述べている11.

手術法に関しては現在一定の見解は得られておらず, 取り残しや再発防止のためには，特に若年者において 遊離体の完全摘出と十分な滑膜切除が望ましいと考え 
られる.このためには脱臼操作が必要と思われるが, 骨頭壊死の危険性があり，可能であれば避けるべきで ある。しかし，臼蓋底に病的滑膜のある場合や遊離体 の残存が危惧される場合は選択される可能性もあり, Ganz アプローチ ${ }^{3)}$ などのより効果的なアプローチ法 の選択や，十分なインフォームドコンセント，残存病 変に対する長期的な経過観察が必要であると考えられ る.

結語

(1)股関節に生じた滑膜骨軟骨腫症の 3 例を経験した.

(2)手術法に関しては，骨頭壊死の危除性を最優先に 考光脱臼操作を行わない手術法を選択し，比較的良好
な成績を得た。

(3)骨頭壊死の危険性が少なく, 術中の視野も良い前 方脱臼を併用した手術法が今後検討される.

$$
\text { 参 考 文 献 }
$$

1）菅野晴夫ら：股関節に発生した滑膜性骨軟骨腫症の 1 例. 仙台市立病院雑誌, $23: 63-67,2003$.

2) 中村知樹ら：単純 X 線像で石灰化像を呈さない股関節 滑膜骨軟骨腫症の 1 例。整形外科, 54 (12) : 1560-1562, 2003.

3）新美 塁ら：Ganzのアプローチを用いて股関節滑膜 骨軟骨腫症に対して手術を行った 1 例。整・災外, 48 ： 779-783, 2005. 